\title{
Guided Inquiry Scratch Increase Students' Critical Thinking Skills on the Linear Motion Concept: Can it be?
}

\author{
Nurhasan Ropi i $^{1,2, a)}$, Wahyu Hardyanto ${ }^{3}$, Ellianawati ${ }^{3}$ \\ ${ }^{1}$ Physics Education, Graduate School, Universitas Negeri Semarang 50237, Indonesia \\ ${ }^{2}$ Junior High School of Banjarharjo 1, Brebes 52265, Indonesia \\ ${ }^{3}$ Department of Physics, Faculty of Mathematics and Sciences, Universitas Negeri Semarang 50229, \\ Indonesia \\ $\bowtie:{ }^{a)}$ nurhasanropii@gmail.com
}

\begin{abstract}
The 4C-oriented 21st-century competency education consists of critical thinking and problem solving, creativity, communication skills, and Ability to Work Collaboratively. Guided inquiry learning strategy combined with scratch technology is needed to train students' critical thinking skills. The study aims to determine the improvement of students' critical thinking skills after being given Guided Inquiry assisted by Scratch media on the Linear Motion concept. The quasiexperimental study with the design of one group pre-post test design was conducted in class VIII B of SMP Negeri 1 Banjarharjo in the academic year 2018/2019. The pre-test results showed that $16.67 \%$ of students were categorized quite critical to very critical and $83.33 \%$ of students in the less critical category were not even critical. The post-test results showed that $91.66 \%$ of students were categorized quite critical to very critical and $8.34 \%$ of students in the less critical category were not even critical. The results of data analysis also showed an increase in students' critical thinking skills by 0.56 with moderate criteria. The application of guided inquiry learning assisted by scratch media can train and increase students' critical thinking skills on the concept of linear motion.
\end{abstract}

Keywords: guided inquiry scratch, critical thinking skills, linear motion concept

\section{INTRODUCTION}

The 4C-oriented 21st-century competency education consists of Critical Thinking and Problem Solving, Creativity, Communication Skills, and Ability to Work Collaboratively (P21 2015). 4C competency is achieved through an effective, continuous learning process and involves the active participation of students. Teaching strategies that involve the participation of students in the learning process through scientific inquiry are more likely to enhance conceptual understanding than strategies that rely on more passive techniques, which are often needed in an educational environment that is full of judgment (Minner et al. 2010). The active involvement of students in learning activities can be done through the application of strategies, models and inquiry-based learning methods.

An inquiry is defined as a series of processes to diagnose problems, criticize experiments, distinguish alternatives, plan investigations, examine the allegations, find information, build models, debate with peers, and form coherent arguments (Vlassi et al. 2013). Inquiry-based learning is based on processes that involve students directly. Students are involved in inquiry-based learning that is meaningful, has true value and relevance, develops high-level thinking skills that are needed (Zubaidah 2016). 
The application of the inquiry learning model can help students to develop critical thinking skills and allow students to build their knowledge as practiced by scientists (Corlu et al. 2012). Inquiry learning which is in line with the development of age and the maturity level of critical thinking of junior high school students is Guided Inquiry learning. It involves structured steps in the form of guiding questions, namely identifying problems, making hypotheses, collecting and analyzing data, making conclusion decisions (Sarwi et al. 2016).

The development of information and communication technology in the era of industry 4.0 is inevitable. The use of technology in online and offline software-based learning media is a prevalent thing and even becomes a necessity amid the swift use of technology in various fields. Sutrisno (2012) states that technology can support inquiry learning, collaboration and repositioning in carrying out the learning process so that the guided inquiry strategy combined with interactive media and worksheet can develop students' critical thinking skills.

The guided inquiry model is integration between material, pedagogic and technology or known as technology pedagogy content knowledge (TPACK). The guided inquiry model that is often carried out has not yet implemented digital technology media. Therefore, there needs to be an update on the use of digital technology media in applying the guided inquiry model. One medium that can be applied in inquiry-based learning is Scratch. Scratch offers interesting and compatible features in the form of animation programs that are integrated both offline and online. Scratch features make it easy for users to learn and apply them to learning. The use of Scratch of learning physics on the concept of gas kinetic theory can improve conceptual understanding, activity, critical thinking skills and creativity of students (Martanti et al. 2013).

The concept of physics about linear motion at the level of junior high school is often taught conventionally to students in the form of general explanations and formulas. As a result, the ability to understand the concept of linear motion by students is not optimal and even misconceptions occurring. The ability to master the concept is closely related to the ability to think critically. Critical thinking ability of students must be trained in learning.

According to Ennis (2011), aspects of indicators of critical thinking include:

1. Elementary clarification, including focusing questions, analyzing arguments, asking questions and answering questions that require explanation or challenge;

2. Basic support, including considering source credibility and considering observations;

3. Inference, including: compiling and considering deduction, compiling and considering induction, arranging decisions and considering the results;

4. Advanced clarification, including: identifying terms and considering definitions, identifying assumptions;

5. Strategies and tactics, including: determining an action and interacting with others.

Critical thinking is a type of important thinking that requires the use of analytical and evaluative cognitive processes and mainly consists of analyzing arguments based on logical consistency with the aim of recognizing false biases and reasoning (Arends 2012).

Several studies on the application of learning media have shown positive results towards improving students' critical thinking skills. The study of Subhan et al (2018) concluded that there was a positive effect of animation media in the guided inquiry learning model of critical thinking skills and learning activities of XI grade students of Makassar Senior High School 21 on the concept of chemical equilibrium. Syahdiani et al. (2015) research added that inquiry-based interactive multimedia is able to improve learning outcomes and train students' critical thinking skills. Therefore, it is necessary to apply the use of scratch media with guided inquiry to improve students' critical thinking skills in the concept of straight motion.

\section{METHODS}

The quasi-experimental research design uses one group pre-post test post design. The study population was all eighth grade students of SMP Negeri 1 Banjarharjo in the 2018/2019 academic year totaling 9 classes. The selection of research samples using purposive sampling technique with the consideration of having the lowest average value in the Semester 1 
Assessment for science subjects compared to other classes. The sample is class VIII B with 36 students.

The research was conducted in three stages, namely: (1) pre test; (2) treatment guided inquiry assisted by scratch media; (3) post test. The Guided inquiry process is conducted through instructions for learning questions on student worksheets that are integrated with Scratch media as a visualization of linear motion concept learning. The research instrument used was five essay tests outlined from the indicators of critical thinking skills.

The analysis of the results of tests of students 'critical thinking skills was first carried out by determining the score on each indicator and the score of each question, according to the scoring criteria that had been determined based on the indicators of students' critical thinking skills. According to Subhan et al (2018), the results of the analysis of critical thinking skills obtained by students during the learning process are categorized in TABLE 1.

TABLE 1. Criteria for Critical Thinking Skills

\begin{tabular}{cc}
\hline $\begin{array}{c}\text { Percentage of critical } \\
\text { thinking skills }(\boldsymbol{\%})\end{array}$ & Category \\
\hline $81-100$ & Very critical \\
$66-80$ & Critical \\
$56-65$ & Quite critical \\
$41-55$ & Less critical \\
$0-40$ & Not Critical \\
\hline
\end{tabular}

To determine the improvement of critical thinking skills, carried out through the analysis of $\mathrm{N}$-gain test using the value of the pre test and post test value. The results of the critical thinking N-gain test was categorized into three criteria: low $(<\mathrm{g}\rangle<0.3)$, moderate $(0.3 \leq<\mathrm{g}>$ $<0.7)$, and high $(<\mathrm{g}\rangle>0.7)$ (Wiyanto 2008).

\section{RESULTS AND DISCUSSIONS}

Learning activities in the classroom begin with pre-test activities. Then, students received treatment with guided inquiry using the scratch media. The guided inquiry process is done through mentoring students' worksheets that are integrated in learning using scratch media. Instructions for learning questions are presented through worksheets and visualized through scratch media. Interactively, students can enter and change the initial data in the form of values of velocity, time, acceleration of objects to see the visualization of the linear motion concept in the scratch media. In the final stage of the learning activity, a post test was conducted to measure students' critical thinking skills. Display of scratch media used in learning is shown in FIGURE 1.

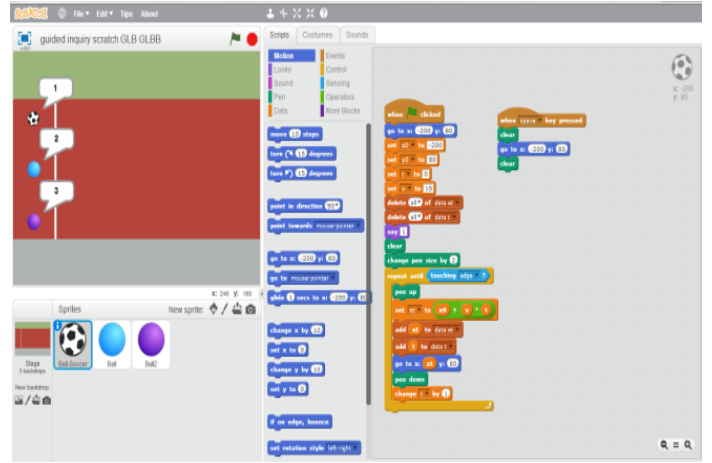

(a)

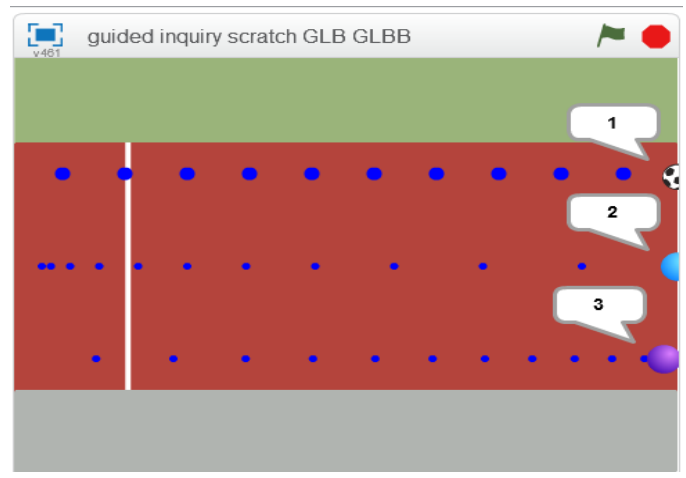

(b)

FIGURE 1. Display the scratch media in the linear motion concept, (a) the ball before moving and (b) the ball after moving 
The results of data analysis in FIGURE 2 about the critical thinking skills of students during the pre-test showed that around $16.67 \%$ of students were categorized quite critical to very critical while around $83.33 \%$ of students were categorized as less critical, even not critical. This is because students have not been trained to develop critical thinking skills through learning activities. The results of data analysis of students' critical thinking skills at the post-test showed that around $91.66 \%$ of students were categorized quite critical to very critical, while around $8.34 \%$ of students as less critical, not even critical. This is because students have been trained to develop their critical thinking skills through the implementation of guided inquiry learning activities assisted by scratch media. Students can provide a simple explanation of the question, express argument, make conclusions and express further explanations about the linear motion concept. Compared with the conditions directed by the teacher, students in guided inquiry conditions showed a significant improvement both in conceptual understanding and in their level of thinking skills in explaining the concept of density (Almuntasheri et al. 2016).

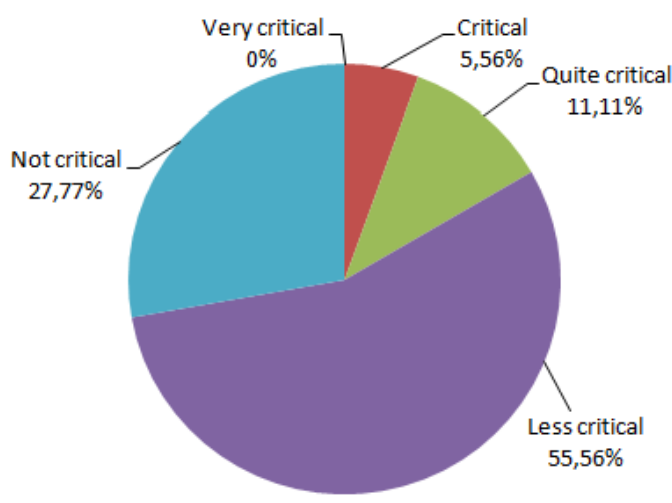

(a)

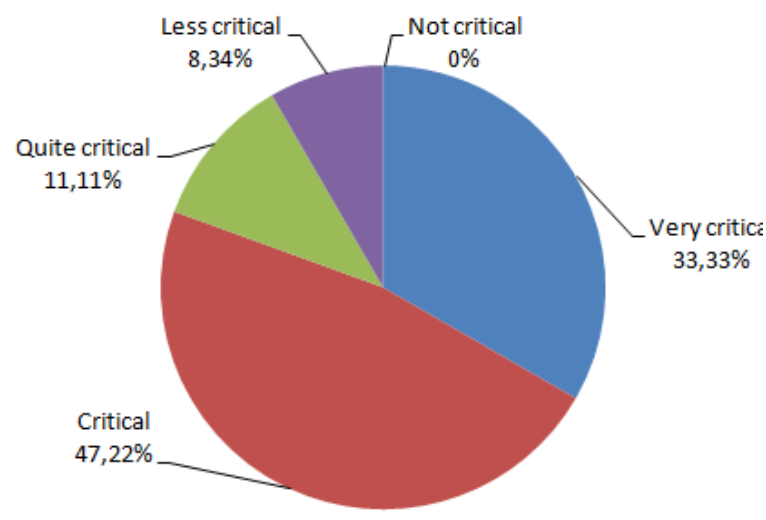

(b)

FIGURE 2. Students' critical thinking skills (a) pre-test and (b) post-test.

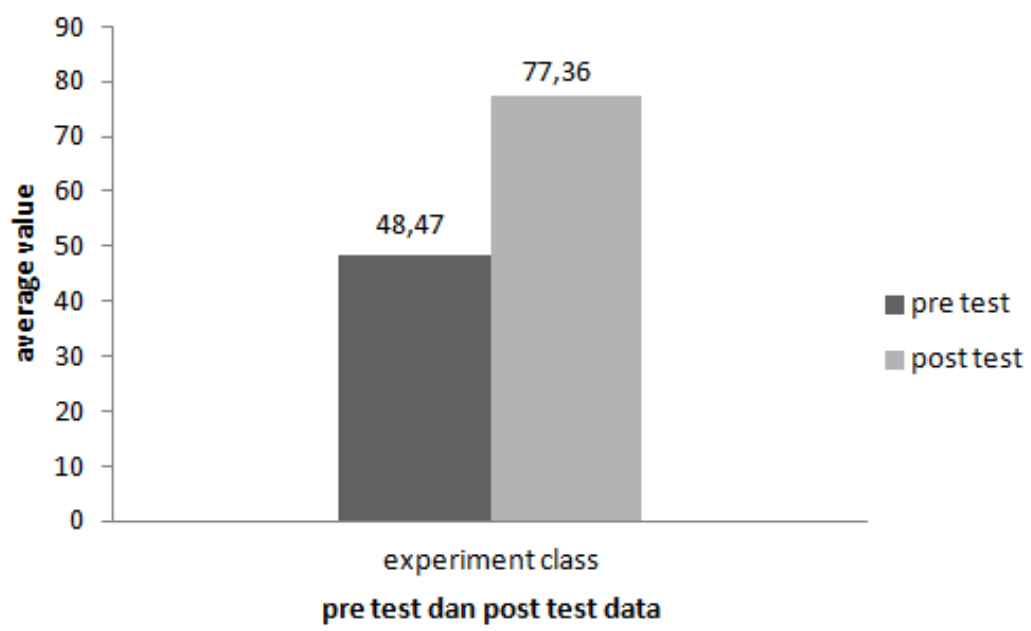

FIGURE 3. N-gain average value of pre-test and post-test.

The results of the $\mathrm{N}$-gain test in FIGURE 3 indicate an increase in the pre-test value to the post-test value of 0.56 with the middle criterion. In this case, guided inquiry learning assisted by scratch media has a positive effect on increasing the value of students. The impact of giving treatment in learning can improve students' critical thinking skills during pre-test and post-test and there is a positive correlation between the value of the pre-test and post-test on the given treatment (Corlu et al. 2012). 


\section{CONCLUSIONS}

The application of guided inquiry learning assisted by scratch media can train and increase students' critical thinking skills in the linear motion concept of 0.56 with medium criteria. Therefore, it is expected that teachers can apply Guided inquiry scratch in linear-motion concept learning.

\section{REFERENCES}

Almuntasheri, S, Gillies, R M \& Wright, T 2016, 'The Effectiveness of a Guided Inquirybased, Teachers' Professional Development Programme on Saudi Students' Understanding of Density', Science Education International, vol. 27(1), pp. 16-39.

Arends, R I, 2012, Learning to Teach Ninth Edition, New York: The Mc Graw-Hill Companies, inc.

Corlu, M A \& Corlu, M S, 2012, 'Scientific Inquiry-Based Professional Development Models in Teacher Education', Education Science: Theory and Practice, vol. 12(1), pp. 514-521.

Martanti, A. P. W, Hardyanto. \& A. Sopyan, 2013, 'Pengembangan Media Animasi Dua Dimensi Berbasis Java Scratch Materi Teori Kinetic Gas untuk Meningkatkan Pemahaman Konsep Peserta didik SMA', UNNES Physics Education Journal, vol. 2(2), pp. 19-25.

Minner, D D, Levy, A J \& Century, J 2010, 'Inquiry-based science instruction-what is it and does it matter? Results from a research synthesis years 1984 to 2002', Journal of Research in Science Teaching, vol. 47, pp. 474-496.

P21, 2015, Framework for 21st Century Learning, http://www.p21.org/our-work/p21framework (download on 26 November 2018).

Sarwi, Sutardi \& Prayitno, W W, 2016, 'Implementation of guided inquiry physics instruction to increase an understanding concept and to develop the students' character conservation', Jurnal Pendidikan Fisika Indonesia, vol. 12(1), pp. 1-7.

Subhan, Salempa, P \& Danial, M 2018, 'Pengaruh media animasi dalam model pembelajaran inkuiri terbimbing terhadap keterampilan berpikir kritis dan aktivitas belajar peserta didik pada materi kesetimbangan kimia', Chemistry Education Review (CER) Pendidikan Kimia PPs UNM, vol. 1(2), pp. 125-141.

Sutrisno 2012, Kreatif mengembangkan aktivitas pembelajaran berbasis TIK. Jakarta: Referensi.

Syahdiani, Kardi, S \& Sanjaya, I G M, 2015, 'Pengembangan multimedia interaktif berbasis inkuiri pada materi sistem reproduksi manusia untuk meningkatkan hasil belajar dan melatihkan keterampilan berpikir kritis peserta didik', Jurnal Pendidikan Sains Pascasarjana Universitas Negeri Surabaya, vol. 5(1), pp. 727-741.

Vlassi, M \& Karaliota, A 2013, 'The comparison between guided inquiry and traditional teaching method. A case study for the teaching of the structure of matter to 8th-grade Greek students', Procedia - Social and Behavioral Sciences, vol. 93, pp. 494-49.

Wang, H \& Posey, L 2011, 'An inquiry-based linear algebra class, online submission', USChina Education Review, vol. B 4, pp. 489-494.

Wiyanto 2008, Menyiapkan Guru Sains Mengembangkan Kompetensi Laboratorium, Semarang: Universitas Negeri Semarang Press. 
Zubaidah, Siti 2016, 'Keterampilan abad ke-21: keterampilan yang diajarkan melalui pembelajaran', Makalah, Seminar Nasional Pendidikan STKIP Persada Khatulistiwa Sintang Kalimantan Barat, December 10, 2016. 